NBER WORKING PAPER SERIES

\title{
CENTRAL BANK CREDIBILITY: \\ WHY DO WE CARE? \\ HOW DO WE BUILD IT?
}

Alan S. Blinder

Working Paper 7161

http://www.nber.org/papers/w7161

\author{
NATIONAL BUREAU OF ECONOMIC RESEARCH \\ 1050 Massachusetts Avenue \\ Cambridge, MA 02138 \\ June 1999
}

I thank the many survey respondents for their kind cooperation, Eleni Constantinou for excellent research assistance, Mervyn King, Robert King, Gregory Mankiw, Laurence Meyer, Frederic Mishkin, Lars Svensson, and Michael Woodford for helpful suggestions, and Princeton's Center for Economic Policy Studies for financial support.. All opinions expressed are those of the authors and not those of the National Bureau of Economic Research.

(C) 1999 by Alan S. Blinder. All rights reserved. Short sections of text, not to exceed two paragraphs, may be quoted without explicit permission provided that full credit, including $\mathbb{C}$ notice, is given to the source. 
Central Bank Credibility: Why Do

We Care? How Do We Build It?

Alan S. Blinder

NBER Working Paper No. 7161

June 1999

JEL No. E5

\section{ABSTRACT}

Central bank credibility plays a pivotal role in much of the modern literature on monetary policy, yet it is difficult to measure or even assess objectively. A survey of central bankers was conducted to determine their attitudes on two important issues: why credibility matters, and how credibility can be built. The central bankers' answers are compared with the responses of NBERaffiliated macro and monetary economists. The two groups agree much more than they disagree. They are particularly united in their evaluations of ways to make a central bank credible -- assigning high ratings to the central bank's track record and low ratings to theoretical ideas like precommitment and incentive-compatible contracts.
Alan S. Blinder
Department of Economics
Princeton University
Princeton, NJ 08544-1021
and NBER
blinder@princeton.edu 


\section{INTRODUCTION}

Over the last 15-20 years, the concept of credibility has become a central concern of the scholarly literature on monetary policy. A search of the 11 economics journals archived in JSTOR (www.jstor.org) reveals that 140 different articles used the word "credibility" in conjunction with either monetary policy or central banking over the 10-year period 1983-1992. ${ }^{1}$ By contrast, a search of the preceding 10 years turns up just 40 references, 23 of which are in the 1980s.

This heightened interest in the credibility of monetary policy pronouncements is, in part, tied to the rational expectations revolution: Under certain assumptions, including rational expectations, a completely credible central bank can engineer a disinflation without suffering any adverse effects on employment. ${ }^{2}$ But central bank credibility is relevant even if expectations are less than fully rational. As long as expectations matter--and how can they not?--a central bank's credibility should influence how its monetary policy actions affect forward-looking variables like long-term interest rates and other asset prices.

Academic economists are far from alone in their preoccupation with the concept of credibility. It is also a central concern in practical central banking circles. Actual policymakers may not believe much in the rationality of expectations; heavy exposure to real-world financial markets has a way of shattering such beliefs. As Fischer Black, who lived successfully in both worlds, is alleged to have said, "Financial markets look more efficient from the banks of the Charles than from the banks of the Hudson." But central bankers nonetheless take it as axiomatic that their credibility affects the linkages from policy changes (or policy pronouncements) to, say, long-term interest rates and exchange rates.

\footnotetext{
${ }^{1}$ The search ends at 1992 because that is as current as JSTOR goes at present.

${ }^{2}$ See Taylor (1983) and Ball (1991) for examples. Ball even shows that, with staggering, a perfectly credible disinflation can cause a boom.
} 
In a word, credibility matters in theory, and it is certainly believed to matter in practice. Empirical evidence on this point, however, is hard to come by because credibility is not easy to measure. ${ }^{3}$ This paper seeks to shed light on two main issues: Why and how? Why is credibility so important to central bankers? And how can a central bank create or enhance credibility?

I investigate these questions in a rather unconventional way. During the summer of 1998, I mailed a questionnaire to the heads of 127 central banks--the entire membership of the Bank for International Settlements ${ }^{4}$--soliciting their opinions on a variety of issues related to central bank credibility. The response rate was gratifyingly (I might say amazingly) high: 84 of the 127 banks responded, for a response rate of $66 \%$. Their answers provide the main data for this study. ${ }^{5}$ While I tabulated the answers for OECD central banks and non-OECD central banks separately, I report here mainly the results for the pooled sample of all central banks because--with only a few exceptions--the two groups gave similar responses. ${ }^{6}$

My primary interest was in the views of actual central bankers. But I sent a substantially identical questionnaire to a similarly-sized sample of (mostly academic) economists who specialize in monetary economics or macroeconomics. ${ }^{7}$ The purpose was to ascertain whether and how the views of the academics differed from those of the central bankers. Differences might emerge for several reasons. Most obviously, the economists are theorists and econometricians rather than practitioners. In addition, almost all of the economists were either raised or educated in the United States (or both)—whereas the central bankers come from 84 different countries. Somewhat to my

\footnotetext{
${ }^{3}$ If the central bank has an explicit, publicly-announced target for some variable $\mathrm{x}(\mathrm{x}=$ inflation, say), then the gap between the target and market expectations can be taken as an objective measure of credibility. But most central banks have no such target.

${ }^{4}$ I deleted the Federal Reserve Bank of New York, which is a BIS member, and included the European Central Bank even though it was not yet conducting monetary policy.

${ }^{5}$ Because I promised anonymity, I cannot acknowledge them by name, but I am extremely grateful to each of the central bankers for their kind cooperation.

${ }^{6}$ T-tests could reject the hypothesis that the mean responses were the same in only three of the 16 questions.
} 
dismay, the response rate among the economists--who are presumably sympathetic to data collection!--was considerably lower, though still respectable: 53 out of 115 returned the questionnaire, for a response rate of $46 \% .^{8}$

Both central bankers and academics apparently consider credibility very important. The questionnaire opened with the following apparently straightforward query:

\section{Q1. How important is credibility to a central bank?}

Actually, this question is not all that straightforward. It begs the question of what "important" means (important for what purpose?), and it leaves the term "credibility" undefined. (A few respondents criticized me for that.) Both omissions were deliberate. A series of subsequent questions inquired about the reasons why credibility might be important to a central bank (see Section 3 below). And I decided not to force any particular definition of the ordinary-English word "credibility" on respondents who might have other meanings in mind and therefore recoil from mine. The term credibility is much used these days, and in a variety of different ways. I wanted to find out why.

In any case, respondents answered by selecting a number on the following five-point scale:

$$
\begin{aligned}
& 1=\text { unimportant } \\
& 2=\text { of minor importance } \\
& 3=\text { moderately important } \\
& 4=\text { quite important } \\
& 5=\text { of the utmost importance }
\end{aligned}
$$

The mean response among the 84 central bankers was a stunningly high 4.83 --with a standard deviation of just 0.37 . Indeed, no respondent chose a number below 4. This is an amazing degree of consensus. The economists are somewhat less enthusiastic about the importance of credibility--and

\footnotetext{
${ }^{7}$ The sampling frame was all members of two NBER programs: Economic Fluctuations \& Growth and Monetary Economics.
} 
also far less unanimous among themselves. Their mean response is 4.23 , which is still quite high, but their standard deviation is 0.85 and six of the 53 economists chose either "2" or "3."

In general, however, I think it fair to say that both groups attach a great deal of importance to central bank credibility. There is thus good reason to read on!

\section{A MATTER OF DEFINITION}

As just noted, I deliberately failed to provide a precise definition of credibility, allowing each respondent to attach his or her own preferred meaning to the term. In fact, there appears to be no generally agreed-upon definition. My own favorite definition involves matching deeds to words: A central bank is credible if people believe it will do what it says. This notion is very close to the (Webster's) dictionary definition: "the ability to have one's statements accepted as factual or one's professed motives accepted as the true ones." But there are many other possible definitions.

In the academic literature, central bank credibility is often identified with one of three things: strong aversion to inflation, incentive compatibility, or precommitment. In some reputational models, a central bank can raise the public's subjective probability that it is "tough" by keeping inflation low. ${ }^{9}$ This probability is, in turn, taken as a measure of the bank's credibility, which is a reasonable enough association if credibility is synonymous with aversion to inflation (more on this below). In other theoretical models, a central bank's pronouncements are credible only if it attains a higher level of expected utility by following through on its promises rather than reneging. In other words, duplicity is to be expected unless truthfulness is in the central bank's self interest. One way to induce the central bank to carry out its pledge to fight inflation is for the

\footnotetext{
${ }^{8} \mathrm{~A}$ few economists listed as members of one of the NBER programs would not normally be considered macroeconomists and may have little involvement in monetary policy issues. One such person graciously returned the questionnaire anyway, but with mostly blank spaces. So, in effect, my sample size is 52 .

${ }^{9}$ Perhaps the classic reference is Backus and Driffill (1985).
} 
government to write an incentive compatible contract for its central bank. ${ }^{10}$ To other theorists, a central bank is not credible unless it is bound by some kind of "commitment technology" to live up to its word. Indeed, the inability to commit to a policy of low inflation is often seen as seriously undermining both central bank credibility and performance. It is often said to be the main reason why central banks allow too much inflation. ${ }^{11}$

Central bankers, it seems to me, use somewhat different, though not contradictory, definitions of credibility. For example, I have often heard central bankers cite the level of a country's long-term interest rates-which presumably reflect inflationary expectations--as a measure of the credibility of monetary policy. Relatedly, a strong track record of fighting inflation is often taken as evidence of high credibility.

One point of contact between policymakers and academics is that many central bankers take the degree of dedication to price stability as synonymous with credibility. Thus the Bundesbank is considered to be one of the world's most credible central banks even though it misses its professed money-growth target more than $50 \%$ of the time. ${ }^{12}$ When people declare that the Bundesbank has high credibility, they mean that no one questions its determination to fight inflation. Similarly, when the United States was disinflating in the 1980s, Federal Reserve Chairman Paul Volcker was considered a highly credible inflation fighter even though his attachment to monetarism was more public relations than substance.

While I did not ask respondents to write down their personal definitions of credibility, the second question on the survey instrument (Q2) asked how closely the concepts of "credibility" and "dedication to price stability" are related. On the following five-point scale:

\footnotetext{
${ }^{10}$ See Walsh (1995) and Persson-Tabellini (1993).

${ }^{11}$ See Barro and Gordon (1983) and the scores of papers it has spawned.

${ }^{12}$ See, for example, Begg et al. (1998), Table B2.1, p. 16, which shows the Bundesbank missing 11 of its last 19 annual target ranges for money growth, even though many of them are three percentage points wide.
} 
1 = unrelated

$2=$ slightly related

$3=$ moderately related

$4=$ quite closely related

$5=$ virtually the same,

the central bankers gave a mean response of 4.10, and nearly $90 \%$ of them answered "4" or higher. Frankly, my experience as a central banker led me to expect an even tighter association. The mean response among the 52 economists was considerably lower--only 3.31; and just over half gave answers of "3" or lower. It thus appears that central bankers identify inflation aversion with credibility more closely than do economists.

\section{WHY IS CREDIBILITY IMPORTANT?}

Immediately following the two preliminary questions already mentioned, the survey instrument offered respondents seven reasons why credibility might be important to a central bank. These reasons are not mutually exclusive; indeed, some are closely related. Each rationale was phrased as an affirmative statement, and respondents were asked to express their agreement or disagreement on the following five-point scale:

$$
\begin{aligned}
& 1=\text { strongly disagree } \\
& 2=\text { disagree } \\
& 3=\text { neutral } \\
& 4=\text { agree } \\
& 5=\text { strongly agree }
\end{aligned}
$$

Before proceeding to the answers, three general observations are worth recording. First, in all seven cases, the central bankers assigned higher average ratings than did the economists. For five of the seven suggested reasons, the difference was statistically significant at the $5 \%$ level by a standard t-test. ${ }^{13}$ I leave it to the reader to muse over whether this systematic discrepancy implies

\footnotetext{
${ }^{13}$ The other two differences would be significant at the $7 \%$ and $9 \%$ levels.
} 
that central bankers agree more with my proferred reasons or are simply easier graders. Second, the distribution of responses across the central bankers was always tighter than the distribution across the economists. While it is often said that economists think too much alike, this criticism apparently does not apply to monetary economists! Third, central bankers and economists generally ranked the seven candidate reasons quite differently; as Table 1 shows, after the first two ranks, there is no similarity in the rankings.

Table 1

Reasons Why Credibility Is Important

\begin{tabular}{|c|c|c|c|c|c|c|c|}
\hline \multirow{2}{*}{$\begin{array}{l}\text { Survey } \\
\text { Question }\end{array}$} & \multirow[b]{2}{*}{ Method } & \multicolumn{3}{|c|}{ Central Banks } & \multicolumn{3}{|c|}{ Economists } \\
\hline & & : & $F$ & $\operatorname{Rank}^{a}$ & : & $\mathrm{F}$ & $\operatorname{Rank}^{\mathrm{a}}$ \\
\hline Q3 & Less costly disinflation & 4.13 & .78 & 2 & 3.83 & 1.12 & 2 \\
\hline Q4 & To keep inflation low & 4.39 & .60 & 1 & 4.17 & .83 & 1 \\
\hline Q5 & To change tactics & 4.38 & .54 & 5 & 3.97 & 1.03 & 3 \\
\hline Q6 & To serve as lender of last resort & 4.12 & .77 & 6 & 3.74 & 1.07 & 4 \\
\hline Q7 & To defend the currency & 4.29 & .70 & 3 & 3.47 & 1.04 & 5 \\
\hline Q8 & Public servants should be truthful & 4.00 & .84 & 7 & 3.30 & 1.07 & 6 \\
\hline Q9 & For support for independence & 4.34 & .75 & 4 & 3.19 & 1.00 & 7 \\
\hline
\end{tabular}

${ }^{\mathrm{a}}$ These are based on ranks given explicitly by respondents, not by mean scores. 


\subsection{Reducing the costs of disinflation (Q3)}

The first of the seven possible reasons appealed to the oft-stated hypothesis that "a more credible central bank can reduce inflation at lower social cost." (Here, and elsewhere, quotations are drawn from the survey instrument.) This so-called credibility hypothesis is supported by some plausible economic theory, which can be summarized in a conventional expectational Phillips curve:

$$
\pi_{\mathrm{t}}=\pi_{t}^{e}-\beta\left(\mathrm{u}_{\mathrm{t}}-\mathrm{u}_{t}^{*}\right)+\gamma \mathrm{z}_{\mathrm{t}}+\varepsilon_{\mathrm{t}}
$$

Here $\pi$ is the inflation rate, $\pi^{\mathrm{e}}$ is its expectation, $\mathrm{u}-\mathrm{u}^{*}$ is the gap between the actual and natural rates of unemployment, $\mathrm{z}$ is a supply shock variable (or vector), and $\varepsilon$ is the disturbance term. Perfectly credible announcements of disinflation will reduce $\pi^{\mathrm{e}}$ abruptly, enabling $\pi$ to fall without the necessity of a period of high unemployment. Even with the price (or wage) stickiness induced by staggered contracts, a disinflation that is preannounced sufficiently far in advance can be costless-or better. ${ }^{14}$

Unfortunately, the empirical evidence is squarely against the credibility hypothesis. Because credibility is not objectively measurable, students of this issue have used central bank independence as a statistical proxy. Using Ball's (1994) constructed measures of the sacrifice ratios in different countries, both Posen (1995) and Fischer (1994) found a surprising positive correlation between central bank independence and the sacrifice ratio-suggesting that more credible central banks actually face worse tradeoffs! Similarly, Debelle (1996) found little evidence that three inflation-targeting nations enjoyed lower costs of disinflation in the 1990s. (Advocates of inflation targeting sometimes advertise it as a way to build credibility.) To my knowledge, there is no statistical evidence whatsoever on the other side of this debate.

\footnotetext{
${ }^{14}$ See Taylor (1983) and Ball (1991) for examples.
} 
Despite the overwhelming weight of the evidence, my personal experience in central banking circles led me to believe that many central bankers accept the notion that greater credibility improves the short-run inflation-unemployment tradeoff. ${ }^{15} 16$ That belief was borne out by the survey results. The central bankers generally accept the credibility hypothesis-their mean rating is 4.11 , which is just above "agree." ${ }^{17}$ When asked to rank the seven candidate reasons explicitly, the credibility hypothesis came in second in mean score with an average rank of $2.96{ }^{18}$

Economists are a bit more skeptical (mean score $=3.83$ ), although in my view not nearly skeptical enough given the lopsided empirical evidence. ${ }^{19}$ There is, however, a great deal of dispersion in the economists' answers to this question: The standard deviation of 1.12 is the largest among the seven candidate reasons. So average opinion is perhaps less meaningful here than for other questions.

Wishful thinking being what it is, one might expect that people who identify credibility more closely with inflation aversion (as measured in Question 2) would express stronger agreement with the credibility hypothesis. However, this turns out to be the case only among the OECD central bankers ( $\rho=0.61)$. Responses to Q2 and Q3 from economists and non-OECD central bankers have correlations of only around 0.15 .

\footnotetext{
${ }^{15}$ See Blinder (1998), p. 65.

${ }^{16}$ As far as I can tell, all central bankers accept the notion that there is no long-run tradeoff between inflation and unemployment-despite the fact that the natural-rate Phillips curve fits the data poorly in most countries other than the United States.

${ }^{17}$ This was the only one of the seven reasons about which the views of OECD and non-OECD central bankers differed significantly. The mean response in the OECD was 4.38 while the non-OECD mean was 4.02.

${ }^{18}$ Question 10 on the survey listed the seven reasons and asked respondents to rank them explicitly from 1 to 7 . The rankings they assigned did not always correspond to the scores they had given in questions 3-9, from which the mean scores shown in Table 1 were computed.

${ }^{19}$ The lower mean score given by economists is not significantly different from the higher mean score given by the central bankers.
} 


\subsection{Helping to keep low inflation (Q4)}

A subtly different version of the credibility hypothesis maintains that, whether or not greater credibility brings down the costs of reducing inflation, "once low inflation has been achieved, a more credible central bank is better able to maintain low inflation." In terms of the simple Phillips curve equation, this presumably means that inflation shocks ( $\mathrm{z}$ or $\varepsilon$ ) are less likely to get embedded in inflationary expectations if the central bank is a more credible inflation fighter.

To me, this idea closely parallels the basic credibility hypothesis (that credibility improves the tradeoff). But survey respondents apparently see the two as somewhat different: The answers

to Questions 3 and 4 correlate around $\rho=0.5$ for both groups. While high for this nearly-orthogonal data set, that is far from a perfect correlation. How can the two hypotheses differ? One possibility is that the second version (credibility helps keep inflation low, Q4) applies only when inflation is already low while the first (credibility makes disinflation easier, Q3) implies that inflation is too high to begin with. A respondent who believes that credibility effects operate better at low inflation might agree with the second hypothesis more than the first.

Whatever the reason, both central bankers and economists agree more strongly with the notion that credibility helps keep inflation low than with the standard version of the credibility hypothesis. The ratings are significantly higher among the bankers $(\mathrm{t}=2.4)$, and higher but not significantly so among the academics $(\mathrm{t}=1.8, \mathrm{p}$-value $=.076)$. Indeed, the notion that more credible central banks find it easier to keep inflation down is the most-highly rated of the seven ideas--by both groups.

\subsection{Flexibility to change tactics (Q5)}

The next three candidate reasons propose circumstances in which credibility might be important to a central bank. I start with the idea that: 
Q5. A more credible central will find it easier to change tactics or operating procedures without upsetting markets or creating doubts about its underlying objectives or its resolve. The notion is that credibility gives a central bank greater tactical or even strategic flexibility. For example, a central bank that is known for its anti-inflation zeal might be able to abandon monetarist operating procedures--as the Volcker Fed did in 1982--without inciting fears that it was abandoning the fight against inflation. Similarly, if the Bank of England had high anti-inflation credibility when it left the European Exchange Rate Mechanism (ERM) in the summer of 1992, it might have been able to do so without raising inflationary expectations.

Central bankers agree with this idea almost as strongly as they do with the previous one $($ mean $=4.38)$. Economists, though still decidedly favorable, agree rather less $($ mean $=3.97)$. But the economists nevertheless rank this idea third among the seven hypothesized reasons why credibility is important, while the bankers rank it fifth.

\subsection{Serving as a lender of last resort (Q6)}

Another situational hypothesis is that:

Q6. A more credible central bank will find it easier to act as a lender of last resort in a financial crisis (e.g., during a market crash or bank run) without creating fears that it has lost its dedication to fighting inflation.

The idea here is that extensive discount-window lending, which raises bank reserves, would normally be considered an expansionary monetary policy. But, if the central bank is credible, such an injection of credit on an emergency basis need not raise inflationary expectations.

Central bankers accord this reason a 4.12 average rating, while economists give it 3.74. But the (numerically) higher score from the central bankers puts the hypothesis in sixth place, while the 
economists rank it fourth. I was surprised to find that practitioners rank the lender of last resort idea lower than the academics.

\subsection{Defending the exchange rate (Q7)}

In countries with fixed or quasi-fixed exchange rates, or even in countries that float their exchange rates impurely, a central bank may from time to time be obligated to "defend its currency against a speculative attack." Can a central bank accomplish this objective better if it is more credible? Central bankers think so--their mean response is 4.29 . But economists are more dubious (mean response $=3.47$ ). The difference in opinion is both statistically significant and economically large.

Note that these favorable responses do not contradict the common notion that fixing the exchange rate may conflict with the dictates of macroeconomic stabilization policy. The survey question explicitly refers to a "speculative attack," which implies short-term intervention during a crisis. The idea is that more credible central banks can more readily scare off speculators. This particular definition of credibility need not call into question policymakers' dedication to fighting inflation--or so the central bankers apparently believe.

\section{$\underline{3.6 \text { A duty to be open and truthful (Q8) }}$}

A quite different reason for thinking credibility important is that "central bankers are public servants, who therefore have a duty to be open and truthful with the public." A confession is appropriate here: This is my personal favorite reason for why a central bank should strive to be

credible, which to me means matching its deeds to its words. ${ }^{20}$ But survey respondents rank it either last (among the central bankers) or next-to-last (among the economists). The mean score for the central bankers is 4.00 (which translates to "agree"); but it is only 3.30 among the economists. Perhaps, as one central banker wrote on his survey, central bankers do not like to think of 
themselves as "public servants."

3.7 Public support for central bank independence (Q9)

The biggest difference of opinion between the central bankers and the economists is over the final suggested reason:

Q9. Credibility is important as a way to justify public support for an independent central bank.

The average rating for this idea among the central bankers is a high 4.34, placing it fourth among the seven reasons. But economists rate it dead last, with a mean score of only 3.19 which is barely above "neutral." Apparently, either the academics do not believe that central bank independence is terribly important (unlikely), or they believe the public will support independence even for a dissembling central bank.

In their written comments, a few central bankers proposed a variant on this reason: A more credible central bank may find it easier to maintain the support of the public when it has to take unpleasant actions.

\section{WHAT MAKES A CENTRAL BANK CREDIBLE?}

The final part of the questionnaire, comprising seven questions, was designed to "inquire into your views on how a central bank can build or create credibility." Each question in this section began with the same words: "To establish or maintain credibility, how important is it that...", and completed the thought by proposing some particular feature of central banking that has been linked to credibility. For example, the first question was:

Q11. To establish or maintain credibility, how important is it that a central bank be independent?

\footnotetext{
${ }^{20}$ See Blinder (1998, pp. 63-64).
} 
Respondents were asked to rate each attribute on the same one-to-five scale used for the survey's first question:

$$
\begin{aligned}
& 1=\text { unimportant } \\
& 2=\text { of minor importance } \\
& 3=\text { moderately important } \\
& 4=\text { quite important } \\
& 5=\text { of the utmost importance }
\end{aligned}
$$

One striking feature of the data gathered in this part of the questionnaire is that, while the economists' ratings are, once again, more disperse and lower than those given by the central bankers, the two groups rank the seven attributes in precisely the same order. (See Table 2.) Hence

\begin{tabular}{|c|c|c|c|c|c|c|c|}
\hline Survey & & $\mathrm{Cel}$ & tral B & & & onon & \\
\hline Question & $\underline{\text { Method }}$ & $:$ & $\underline{F}$ & $\underline{\operatorname{Rank}}^{\mathrm{a}}$ & $:$ & $\mathrm{F}$ & Rank $^{\mathrm{a}}$ \\
\hline Q11 & Central bank independence & 4.51 & .63 & 2 & 3.99 & .86 & 2 \\
\hline Q12 & Transparency & 4.13 & .71 & 4 & 3.44 & 1.18 & 4 \\
\hline Q13 & History of honesty & 4.58 & .52 & 1 & 4.30 & .80 & 1 \\
\hline Q14 & History of fighting inflation & 4.15 & .67 & 3 & 3.83 & .86 & 3 \\
\hline Q15 & Constrained by a rule & 2.89 & 1.01 & 6 & 2.32 & 1.06 & 6 \\
\hline Q16 & Incentives (personal loss) & 2.15 & 1.10 & 7 & 1.95 & .96 & 7 \\
\hline Q17 & Small fiscal deficit/debt & 3.92 & .93 & 5 & 3.27 & 1.14 & 5 \\
\hline
\end{tabular}
I will present their answers in order of expressed importance, rather than in the order in which the questions appeared on the survey.

Table 2

How to Build Credibility

${ }^{\mathrm{a}}$ Ranked by mean scores. 


\subsection{A history of living up to its word (Q13)}

The top-rated way for a central bank to establish credibility, according to both groups, is to "have a history of doing what it says it will do." Central bankers give this notion a very high mean rating of 4.58, while economists give it 4.30. The cross-sectional standard deviation within both groups is also the lowest across the seven methods, indicating an unusually high degree of consensus. Indeed, all but one of the 84 central bankers rate this idea as either "quite important" or "of the utmost importance," as do 47 of the 51 economists.

In contrast to some naive interpretations of rational expectations, in which credibility can be created or destroyed abruptly by, say, announcing or legislating an institutional change, our respondents believe that a consistent track record matters most for credibility. ${ }^{21}$ This strong consensus choice of both central bankers and economists seems to correspond closely to the dictionary definition offered earlier in this paper. It also accords with my own beliefs about how credibility is created. I wrote in Blinder (1998, p. 65) that:

In the real world, such credibility is not normally created by incentive-compatible compensation schemes nor by rigid precommitment. Rather it is painstakingly built up by a history of matching deeds to words. A central bank that consistently does what it says will acquire credibility by this definition almost regardless of the institutional structure.

I was not surprised to find central bankers strongly agreeing with this sentiment. But I was a bit surprised to learn that academics rate it so much higher than the institutional arrangements that have been emphasized in the literature--such as central bank independence, precommitment, and incentive-compatible contracts.

\footnotetext{
${ }^{21}$ This is hardly a brief against rationality. The historical record is quite relevant in models of rational expectations with learning.
} 


\subsection{Central bank independence (Q11)}

The idea that a central bank builds credibility through a history of living up to its word (Q13) even out-scores the central bankers' holy grail (and second-place finisher), central bank independence. The margin of victory looks slender (mean $=4.51$ vs. 4.58$)$ and is statistically insignificant among the central bankers. But the average ranks that central bankers assign to the two reasons are more disparate $(4.25$ vs. 2.96$)$. So there is daylight showing. The gap in average score is wider and almost statistically significant among the academic economists (mean $=3.99$ vs. $4.30, t=1.9)$, but the difference in average rank is smaller (3.66 vs. 3.08).

There is a tantalizing suggestion in these results: that independent central banks that lack a track record may be less credible than even non-independent central banks that have a good track record. Is there a lesson here for the European Central Bank? The economists apparently think so, albeit by a narrow margin.

\subsection{A history of fighting inflation (Q14)}

Next in the Table 2 ranking comes the idea "that a central bank [should] have a history of fighting inflation" if it wants to establish its credibility. Note that inflation fighting may well differ from the top-ranked method: keeping your word (Q13). The most prominent example, as I have mentioned before, is the Bundesbank, whose sterling record of fighting inflation coexists with a checkered history of meeting its self-proclaimed monetary targets.

While both central bankers and economists attach considerable importance to having a history of inflation fighting (mean ratings of 4.15 and 3.83 respectively), both rank it as notably less important than doing what you say (mean ratings of 4.58 and 4.30 ). Honesty, in their view, is a more important credibility-builder than inflation aversion. Nor are the two the same. The 
correlation between the answers to the two questions about the central bank's history (Q13 and Q14) range between 0.23 and 0.33 over the three groups of respondents.

\subsection{Openness and transparency (Q12)}

The next way to establish credibility--being open and transparent--fell squarely in the middle of the rankings: fourth on a list of seven candidate methods, with an average rating of 4.13 from the central bankers and 3.44 from the economists.

I was frankly surprised to learn that central bankers view openness as such a fine way to build credibility. This may be a recent development. After all, the traditional view in centralbanking circles prizes secrecy and even a little mystery in monetary policymaking. ${ }^{22}$ Too much openness is sometimes portrayed as a threat to credibility. If you keep your mouth shut (and your blinds drawn), the argument goes, no one will be able catch you changing your mind. Such changes of mind, it is alleged, undermine a central bank's credibility.

Apparently, most central bankers no longer accept this argument--if indeed they ever did. However, one policymaker explicitly mentioned that an open central bank can lose credibility by changing its policy frequently, and another insisted that truthfulness (which he favors) does not require openness (which he does not). Recent trends in central banking seem to be moving strongly in the direction of greater transparency, however, with such institutions at the Bank of England and the Reserve Bank of New Zealand in the vanguard. Both of these central banks explicitly adopted inflation targeting and a high degree of transparency in attempts to create credibility from scratch.

4.5 Fiscal discipline by the government (Q17)

Central banks, even if independent, cannot control the budgetary policies of their governments--as one of the central bankers explicitly noted on his questionnaire. A large fiscal

\footnotetext{
${ }^{22}$ Hence William Greider's provocative title, Secrets of the Temple. On central bank secrecy, see Goodfriend (1986).
} 
deficit (or debt) can undermine central bank credibility in a number of ways. Most obviously, if the country has a limited (or zero) capacity to float interest-bearing debt, the central bank may be forced to monetize any budget deficits--with inflationary, or even hyperinflationary, consequences. This danger is greater if the central bank lacks independence. The unhappy experiences of several Latin American countries in the 1960s, 70s, and 80s and Russia in the early 1990s are well-known examples.

But even if massive inflationary finance is unlikely, outsized fiscal deficits and/or large accumulations of public debt (relative to GDP) put upward pressure on interest rates, which may induce a more accommodative policy from the central bank. For example, a common monetarist criticism of U.S. monetary policy in the 1960s was that, by pegging the nominal interest rate, the Fed forced itself to respond to any fiscal expansion with an accommodating monetary policy.

The stock of debt is also sometimes thought to threaten the central bank's credibility. For example, prior to EMU convergence, Italy's large public debt was often seen as an inflationary sword of Damocles hanging over the head of the Bank of Italy. The fear was that the central bank would "eventually" have to monetize (some of) it.

One economist and one central banker, however, reversed the line of causation. The economist pointed out that the inflation premium in interest rates, and therefore the budget deficit, will be lower when the central bank is more credible. The central banker hypothesized that a more credible central bank might be better able to pressure its government into exerting more fiscal discipline. In both hypothetical cases, greater central bank credibility leads to smaller budget deficits.

Central bankers, not surprisingly, attach rather more importance to the fiscal factor (mean score $=3.92)$ than do economists $($ mean $=3.27)$, although both rate it only fifth among the seven 
methods for creating credibility. ${ }^{23}$ Given their countries' greater ability to cover deficits by issuing bonds, one might expect the fiscal situation to be of less concern to OECD central bankers than to non-OECD central bankers. That expectation is borne out by the difference in mean scores $(3.61$ among OECD central banks versus 4.06 outside the OECD), which barely misses significance at the $5 \%$ level $(\mathrm{p}=0.052) .^{24}$

\section{$\underline{4.6 \text { Precommitment (Q15) }}$}

There is some ambiguity in the use of the word "rule" in the context of monetary policy, as a few respondents noted. For example, Friedman's k-percent money growth rule is clearly a rule by anyone's definition. But what about inflation targeting (one economist explicitly raised this question), or the so-called Taylor rule? The specific question on the survey was:

Q15. To establish or maintain credibility, how important is it that a central bank's governor(s) be bound (whether by law or by custom) to follow a prescribed rule that constrains their decisionmaking?

In phrasing this question, I intended the words "bound" and "constrains their decisionmaking" to evoke the rules-versus-discretion debate in the minds of the academics without using jargon terms (like "commitment technology") that might be meaningless to central bankers. But there may be no bright line between rules and discretion. For example, Bernanke and Mishkin (1997) call inflation targeting a form of "constrained discretion."

It is hardly surprising that central bankers, who pride themselves on good judgment, are less than enamored of the idea that credibility can be established by tying their hands with some kind of

\footnotetext{
${ }^{23}$ A data problem must be mentioned here. Due to a flaw in producing the questionnaire, the five-point scale failed to appear immediately below this question-which was the last one on the questionnaire - as it did after all the others. Most respondents answered anyway, using the five-point scale that was already familiar to them. But 9 central bankers and 10 economists did not. So sample sizes are smaller for this question.

${ }^{24}$ One needs to remember that, with the addition of Poland, the Czech Republic, Hungary, South Korea, and Mexico, the OECD is no longer a "rich countries' club."
} 
rule. The mean score of 2.89 , which ranks it sixth among the seven methods, corresponds to something below "moderately important."

What is more surprising is that academic economists, many of whom (I thought!) believe in the importance of commitment technologies, rate the idea even lower. Their mean score of 2.32 attaches only a little more than "minor importance" to rules, which leaves one wondering why so much academic ink has been spilled over this issue.

\subsection{Incentive compatible contracts (Q16)}

Once again, I did not use the term "incentive-compatible contracts" in order to minimize jargon. Instead, I asked both central bankers and academics a more specific question:

Q16. To establish or maintain credibility, how important is it that a central bank's governor(s) suffer some personal loss (e.g., a lower salary or loss of job) when inflation is $\underline{\text { too high? }}$

This interpretation of the contract approach may take Walsh's (1995) interesting idea too literally. But I stoutly reject the idea that loss of reputation alone can serve as the penalty in the (implicit) contract--as three survey respondents suggested. If failure to live up to the terms of the contract is a sufficient incentive, then every contract is incentive compatible. Let me be clear about this. I do agree wholeheartedly with the idea that damage to one's reputation as a central banker is an effective disciplinary device. But that loss is suffered even in the absence of any contractual arrangement, and it seems far closer to some of the previously discussed methods of establishing credibility--such as a track record of honesty or inflation fighting--than to the contract approach.

In any case, neither central bankers nor academic economists see personal incentives as an important way to build credibility. Both rank it dead last, with a mean score of 2.15 from the bankers and 1.95 from the economists. Once again, the low rating from the central bankers was 
expected, but I thought incentive compatibility would be rated more highly by a panel of academics, given the voluminous literature on the idea.

\section{CONCLUSIONS}

Credibility is prized by central bankers, who associate it with devotion to fighting inflation, though perhaps not as closely as you might suppose. While central bankers agree with all seven of my proposed reasons why credibility is important, they favor four: Greater credibility makes disinflation less costly, helps hold down inflation once it is low, makes it easier to defend the currency, and helps garner public support for central bank independence. Economists generally like the seven reasons a bit less and have more disparate views. Although they agree on the top two ranked reasons (keeping inflation low, and reducing the costs of disinflation), beyond that they assign markedly different rankings than the central bankers.

When it comes to appraising methods of building or creating credibility, the views of central bankers and economists are closely aligned. Establishing a history of living up to its word is ranked first, by a narrow margin by the central bankers and by a wide margin by the economists. Central bank independence is ranked second. Two of the methods most emphasized in the scholarly literature that followed Barro and Gordon (1983)--precommitment and incentive compatible contracts--are rated as least important by both groups of respondents.

In brief, there appear to be no shortcuts to greater credibility. Respondents think central banks get their credibility the old-fashioned way: They earn it by building a track record for honesty and inflation-aversion (in that order of importance), not by limiting their discretion via commitment technologies or by entering into incentive-compatible contracts. Bagehot, who 
predated Kydland and Prescott (1977) by a few years, would probably find these results unsurprising.

\section{Bibliography}

Backus, David, and E. John Driffill, "Rational Expectations and Policy Credibility Following a Change in Regime," Review of Economic Studies, LII (1985), 211-21.

Ball, Laurence, "What Determines the Sacrifice Ratio?", in Monetary Policy (edited by N. Gregory Mankiw), National Bureau of Economic Research, University of Chicago Press, 1994, 155-193.

Ball, Laurence, "The Genesis of Inflation and the Costs of Disinflation," Journal of Money, Credit and Banking, August 1991, Part 2, 439-452.

Barro, Robert J., and David Gordon, "A Positive Theory of Monetary Policy in a Natural Rate Model," Journal of Political Economy 91, August 1983, 589-610.

Begg, David, Paul De Grauwe, Francesco Giavazzi, Harald Uhlig, and Charles Wyplosz, The ECB: Safe at Any Speed?, Center for Economic Policy Research, October 1998, 45 pp.

Bernanke, Ben S., and Frederic S. Mishkin, "Inflation Targeting: A New Framework for Monetary Policy?" Journal of Economic Policy, Spring 1997, 97-116.

Blinder, Alan S., Central Banking in Theory and Practice, (Cambridge, MA: MIT Press, 1998.

Debelle, Guy, "The End of Three Small Inflations: Australia, New Zealand, and Canada," Canadian Public Policy 22, 1996, 56-78.

Fischer, Stanley, "Modern Central Banking," in The Future of Central Banking by F. Capie et al., Cambridge University Press, 1994, 262-304.

Goodfriend, Marvin, "Monetary Mystique: Secrecy in Central Banking," Journal of Monetary Economics 17, January 1986, 63-92.

Greider, William, Secrets of the Temple (New York: Simon \& Schuster), 1987.

Kydland, Finn E., and Edward C. Prescott, "Rules Rather than Discretion: The Inconsistency of Optimal Plans," Journal of Political Economy 85, June 1977, 473-492.

Persson, Torsten, and Guido Tabellini, "Designing Institutions for Monetary Stability," CarnegieRochester Conference Series on Public Policy 39, December 1993, 53-84. 
Posen, Adam S., "Central Bank Independence and Disinflationary Credibility: A Missing Link?" Federal Reserve Bank of New York, 1995, photocopy.

Taylor, John B., "Union Wage Settlements During a Disinflation," American Economic Review 73, December 1983, 981-993.

Walsh, Carl E., "Optimal Contracts for Central Bankers," American Economic Review 85, March 1995, 150-167. 